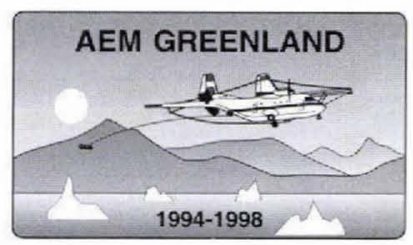

\title{
Airborne geophysical surveys in 1995
}

\author{
Leif Thorning and Robert W. Stemp
}

Two major airborne geophysical surveys were carried out during 1995, the second year of a planned five-year electromagnetic and magnetic survey programme (project AEM Greenland 1994-1998) financed by the Government of Greenland, and the first year of an aeromagnetic survey programme (project AEROMAG 1995-1996) jointly financed by the governments of Denmark and Greenland; both projects are managed by the Geological Survey of Denmark and Greenland (GEUS). The budget for each of the surveys is in the order of one million US dollars per year. The two 1995 survey areas are shown in Fig. 1, where the AEM Greenland 1994 survey area (Stemp \& Thorning, $1995 \mathrm{a}, \mathrm{b})$ and the surveys planned for 1996 are also shown. Summary information concerning the two 1995 surveys is listed in Table 1.

The date of public release of data is 1 March 1996 for both surveys, in accordance with the primary objective to stimulate commercial mineral exploration in Greenland by making the data quickly available to the mining industry. The data acquired are included in geoscientific databases at GEUS for public use; digital data and maps may be purchased from the Survey. The main results from the 1995 surveys are published in Stemp (1996) and Thorning \& Stemp (1996).

\section{Project AEM Greenland 1995: Maniitsoq - Nuuk, southern West Greenland}

The main objective of this survey was to investigate the 'norite belt' in the Maniitsoq - Nuuk area, which is known for its occurrences of disseminated sulphides and where kimberlite dykes have been observed. The survey was flown between 15 July and 11 September 1995 by Geoterrex Ltd (Canada) using a CASA aircraft with geophysical equipment. Cominco Ltd holds extensive mineral exploration licences in the area, and provided a financial contribution towards the survey. Cominco staff also provided valuable pre-survey technical assistance and had full access to the data in the field; however, Cominco has no special rights to the data after the general release date.

Survey equipment and technical specifications were similar to those used for the first survey of the AEM Greenland project over Inglefield Land in 1994 (Stemp \&
Thorning, 1995a, b) with two major exceptions: survey line spacing was reduced from $400 \mathrm{~m}$ to $200 \mathrm{~m}$ over the central part of the survey area, where norite occurrences are especially numerous, resulting in more detailed maps at scale $1: 20000$ of this part of the survey area; and a z-axis GEOTEM receiver coil was added to provide potentially greater depth of exploration and improved anomaly source discrimination.

Survey operations were based at Nuuk airport, where hangar facilities were available; the international airport Kangerlussuaq (Søndre Strømfjord), was used as a refuel-

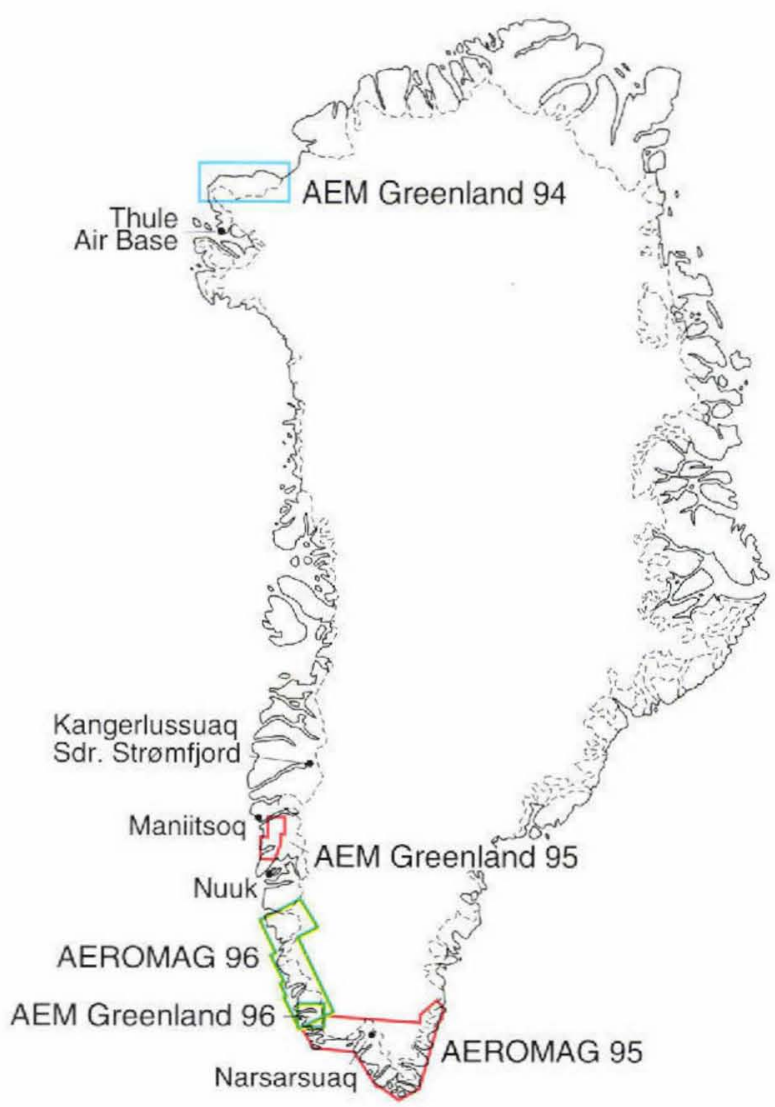

Fig 1. Index map showing the three surveys already flown in projects AEM Greenland 1994-1998 and AEROMAG 1995-1996 and the two surveys planned for 1996. 
ling base on some days with two flights. The field processing was undertaken in Nuuk.

Compared with the 1994 survey over Inglefield Land flown from Thule Air Base, average production per hour and per day was significantly higher in 1995, primarily due to the much shorter ferry distance to the survey area, and despite the fact that more days were lost due to bad weather in 1995.

As anticipated in the planning of the survey, the rough terrain was a serious problem for fixed-wing surveying in parts of the Maniitsoq - Nuuk region. This necessitated some compromise in selecting survey boundaries and flight line direction. However, the AEM Greenland 1995 survey resulted in the successful acquisition of more than 20000 line $\mathrm{km}$ of high sensitivity, airborne electromagnetic and magnetic data, including some reconnaissance lines flown south and east of the survey area. The average sampling distance along lines was 7-10 m, which combined with the close line spacing provides a very detailed data set revealing a wealth of geological information. Results of the project in the form of digital data, maps, processing report and preliminary interpretation report are now available from the Survey (Stemp, 1996).

\section{Project AEROMAG 1995: South Greenland}

This extensive and ambitious, high sensitivity airborne magnetic survey of South Greenland was carried out in order to map regional geological structures throughout the region, especially under the Inland Ice, and to gain a better understanding of the complex geology of the area.

The programme was extremely challenging for a number of reasons. The obstacles for airborne surveying that had to be overcome included some of the most severe terrain in Greenland, ranging in elevation from sea level to over $2000 \mathrm{~m}$, with extensive areas covered by either the Inland Ice or by sea water with uncertain depths to underlying bedrock surfaces.

The project was flown by Sander Geophysics Ltd (Canada) during approximately seven months of surveying, which started on 13 August 1995, almost three months later than originally planned. The base was at Narsarsuaq airport, where hangar facilities were made available. As Narsarsuaq is the only suitable airport in the area, extra safety measures had to be undertaken, as the region is known both for its notorious and unpredictable bad weather and turbulence generated by the Inland Ice and local ice caps.

Table 1. Summary information for the two 1995 geophysical surveys

Project:

Objectives:

Size:

Flight line spacing:

Tie line spacing:

Survey altitude:

Contractor:

Base of operation:

Geophysical sensors:

Navigation:

Aircraft:

Survey dates:

Production/aircraft day:

Total cost:

Cost/line km:

Financing government:
AEM Greenland 1995

Detailed geophysical mapping

Detailed geological mapping

Detection of massive sulphides

Detection of kimberlite pipes

20500 line $\mathrm{km}$

200 or $400 \mathrm{~m}$

$4 \mathrm{~km}$

$120 \mathrm{~m}$ terrain clearance

Geoterrex Ltd, Canada

Nuuk

GEOTEM electromagnetics

Caesium magnetometer

Differential GPS

one CASA

15 July $95-11$ Sept 95

345 line $\mathrm{km}$

DKK 6.0 mill.

DKK 270

Greenland

\section{AEROMAG 1995}

Regional geophysical mapping

Regional geological mapping

Relate east and west coasts of South Greenland

89500 line $\mathrm{km}$

$500 \mathrm{~m}$

$5 \mathrm{~km}$

$300 \mathrm{~m}$ drape

Sander Geophysics Ltd, Canada

Narsarsuaq

Caesium magnetometer

Differential GPS

one Cessna 402

one Beachcraft Queenair

13 Aug 95 - 15 Feb 96

455 line $\mathrm{km}$

DKK 5.5 mill.

DKK 60

Greenland / Denmark 
Table 2. Productivity data for AEROMAG 1995

\begin{tabular}{lccc}
\hline Month & Aircraft days & $\mathrm{km}$ flown & $\mathrm{km} /$ aircraft days \\
\hline Aug & 19 & 7201 & 379 \\
Sep & 40 & 10622 & 266 \\
Oct & 55 & 41688 & 758 \\
Nov & 30 & 7592 & 253 \\
Dec & 12 & 3723 & 310 \\
Jan & 21 & 4292 & 204 \\
Feb & 37 & 9184 & 248 \\
Mar & 15 & 5453 & 364 \\
\hline
\end{tabular}

A further complication was the limited daylight hours in late autumn and winter, and the fact that geomagnetic activity is usually high in the region. These difficulties are reflected in the strongly varying productivity figures listed in Table 2.

Two specially equipped twin-engine aircraft were used, although not continuously, to complete the programme of approximately 90000 line $\mathrm{km}$. A computer assisted drape flying programme, designed and tested during this survey by Sander Geophysics Ltd, was used for the first time during this project. It enabled the flight crews to maintain an optimal drape position at all times, thus minimising problems usually associated with terrain clearance in mountainous regions, and producing both a better and a safer survey. The method is based on a digital elevation model which combines terrain data for the region with slopes adjusted to the optimal rate of climb and descent of the aircraft used for the survey. The aircraft autopilot uses this model to position the aircraft on the optimal drape surface, ensuring better continuity both along and across survey flight lines.

Data from the AEROMAG 1995 project will be compiled at scale 1:50 000 (42 map sheets) and at 1:250 000 ( 2 map sheets). The Survey report discussing the results is expected to be available in mid- 1996 .

Acknowledgements: The staff of both Geoterrex Ltd and Sander Geophysics Ltd are acknowledged for their dedicated approach to the successful completion of both projects. The Government of Greenland, Minerals Office, gave valuable assistance to Geoterrex Ltd in Nuuk and to the Survey personnel supervising the operations. Airport authorities, agencies and companies at the three airports involved are thanked for their assistance to the crews from Geoterrex Ltd and Sander Geophysics Ltd.

\section{References}

Stemp, R. W., 1996 : Airborne electromagnetic and magnetic survey of the Maniitsoq - Nuuk area, southern West Greenland. Geol. Surv. Denm. Greenl. Report 96/11, 34 pp.

Stemp R. W. \& Thorning, L. 1995a: A new airborne electromagnetic and magnetic survey of Inglefield Land, North-West Greenland: Project AEM Greenland 1994-1998. Rapp. Grønlands geol. Unders. 165, 64-68.

Stemp R. W. \& Thoming, L. 1995b: Airborne electromagnetic and magnetic survey of Inglefield Land, North-West Greenland. Open File Ser. Grønlands geol. Unders. 95/1, 45 pp.

Thorning, L. \& Tukiainen, T. 1995: Landsat image database for Greenland. Rapp. Grønlands geol. Unders. 165, 76-78.

L.T. \& R. W. S., Geological Survey of Denmark and Greenland, Copenhagen 